\section{Urban Population Growth and Job Opportunities: The Case of Albania}

\author{
Mario Çurçija \\ University “LuigjGurakuqi”, Faculty of Economy, Albania \\ mario.curcija@unishk.edu.al

\section{Emirjeta Bejleri} \\ University “LuigjGurakuqi”, Faculty of Economy, Albania \\ emirjeta.bejleri@unishk.edu.al
}

\begin{abstract}
Demographic change is a complex phenomenon, but it has generally been accepted that having better employment opportunities and quality of jobs are among important factors that determine people's mobility. The purpose of this paper is to test the relationship between the increase in the number of people living in urban areas and the job opportunities in these areas in Albania. In order to do so, we performed a statistical analysis of a dataset on labor force surveys for the time period of 2007-2013. Our findings confirmed a positive correlation between the increase of individuals living in a certain area and job opportunities for specialized occupations in that area; however, a significant relationship was not found when job opportunities in general, in general, were considered.
\end{abstract}

Keywords: urban population growth, job opportunity, Albania, transition economies, demographic change, internal migration

\section{The Main Topic and Research Questions}

While polarization in the development of different areas of a country is a complex phenomenon influenced by socioeconomic, demographic, location, and other factors (Pociūtè-Sereikienė, 2019), demography and employment play an important role. Job opportunities and the quality of the work job quality are an important aspect of human life and a major cause of mobility, which in the end can be deterministic of growth of some areas, and reduction of growth in others. while some others shrink.

Uneven developments, depopulation, and shrinking cities are both a national and a local issue. Depopulation poses a risk about to the sustainability of the welfare state. As it is associated with an aging population aging, which implies an increase in public spending on pensions and health cures. Depopulation is also associated with economic slowdowns or recessions, because of the lack orfe migration of young people who are potential local leaders, founders, and managers of new businesses (Headey \& Hodge, 2009; see also Maestas, Mullen, \& Powell, 2016). It may lead to a downward spiral as the departure of young and skilled people determines an economic downward downturn that is associated with high unemployment, lack of security and criminality, and social problems (Šerý, Svobodová, Šilhan, \& Szczyrba, 2017).
ORIGINAL SCIENTIFIC PAPER

RECEIVED: MARCH 2020

REVISED: AUGUST 2020

ACCEPTED: NOVEMBER 2020

DOI: 10.2478/ngoe-2020-0021

UDK: 331.108.3:911.375

JEL: J19, J69, P20

Citation: Çurçija, M., \& Bejleri, E. (2020). Urban Population Growth and Job Opportunities: The Case of Albania. Naše gospodarstvo/Our Economy, 66(4), 28-39. DOI: 10.2478/ngoe-2020-0021
NG OE

NAŠE GOSPODARSTVO OUR ECONOMY

\begin{tabular}{l|l|l} 
vol. 66 & No. 4 & 2020 \\
\hline
\end{tabular}

pp. $28-39$ 
In this paper, we have referred to the resident urban population by district in Albania. According to the Constitution, Albania is a unitary state with two levels of local government: the municipality / communes at the first level and the district at a higher level. During the period to which this paper refers, there were 308 communes, 65 municipalities, and 12 districts. The district consists of several basic units of local government with economic and social ties and it is the administrative unit where regional policies are built created and implemented and where they are harmonized with state policy.

This paper, which focuses on referred to the Albanian situation specifically, will address the following questions: is there a relationship between city dimensions, the urban population, and job opportunities? If so, what kinds of jobs are more affected?

\section{The Literature on Demographic Change in Transition Countries}

Steady depopulation of rural areas and population concentration, of population and economic activities in Eastern European countries - the so-called “compression" of social and economic space - has been the subject of studies of several research papers seeking to identify any general pattern or determinants of income disparities across regions (Chapman \& Meliciani, 2018; see also Romanova, Vinogradova, \& Frizina, 2015). The transformations in Eastern Europe, that has led have led to the emergence of a handful of dynamic metropolitan areas on one hand and to some underdeveloped, scarcely- populated peripheral regions, on the other hand. This has been, reflected in the concentration of highly educated and internationally- oriented professionals and entrepreneurs located mainly in metropolitan areas (Smetkowski, 2013).

Shrinking populations because of de-industrialization is a well-known phenomenon in western countries. In Eastern Europe, after the collapse of the communist regime, depopulation was widespread. had remarkable proportions after the collapse of the communist regime. Most of the post-communist Eastern European countries have faced the problem of having some cities shrink and others becoming highly urbanized and overpopulated the shrinkage of some cities and few others urbanization and overpopulation (Turok \& Mykhnenko, 2007; see also Haase, Grossmann, \& Rink, 2016). 40\% of all European cities with more than 200,000 inhabitants' areas shrinking or losing population over the short-, medium- and even long-term periods (Turok \& Mykhnenko, 2007).
The demographic change in transition countries is a complex process, and it is difficult to summarize it into a unifying model. The metropolitan areas and the regions of the transition countries that are near EU in the nearby with EU countries have tended to adapt faster to the new economic conditions (Petrakos, 2001).

In the case of Albania, shrinking in some areas and thriving in some others is has been related to several factors which that can be summarized in three categories: political factors, economic factors, and social factors, although the separation between them, however, is not definitive because often economic factors determine the fate of political initiatives and vice versa.

Political factors refer to the removal of the restrictions to on free movement after the fall of the communist system. According to the communist ideal, the centralized planning included almost every aspect of human existence and among them, restriction applied to the free movement of workers. The utopian ideal was egalitarianism, translated as a compulsory equalization of (quality of life in all areas. The aim was not just to improve the quality of the individuals but also the quality of life of the individuals in the country where they were born and raised. Although not completely inexistent, mobility was restricted by the right to buy a home - real estate was public) - and a special authorization was even required to be transferred to another city. Mobility was limited by the right to work, and as the enterprises were public, eventually to search and find a new job without the authorization of political leadership was impossible. This controlled planning limited the natural growth of the population of major cities. The population of Tirana, Durres, Shkodra, and Vlora in the period of 1945-1989 grew 50\% less than the population growth in Albania (Kopliku, 2016). These restrictions confined $70 \%$ of the population in rural areas and created a potentially explosive situation that was precipitated after the 1990. The removal of restrictions on free movement started an inexorable process of population shrinkage in the rural areas.

Among the economic factors that determined the movement of the population are was the reduced state's role in the economy, the closure of public enterprises and state industries, the shrinkage of state administration, and the consequent massive job cuts. The increase of unemployment has been one of the major reasons for the huge emigration since 1990, a third of the population (Instat, 2018), as well as the massive internal migration from inner areas to western urban centers (Instat, 2014).

Regarding the social factors, we must note that contraction of the state's role in the economy determined a reduction 
in public services and the withdrawal own from public services such as transport, education, health, and social assistance in rural and mountainous areas. Public services cuts have worsened the quality of life and for the people, especially in the hinterlands, who had decided to abandon their homes. But gradually, this shrinking of the population made the presence of some other public services not justifiable, which have which are further reduced. This phenomenon progressively leads the system into a sort of vicious circle. The closure of the production activities such as large public enterprises and the reduction of social services lead to rising greater unemployment, which was becomes reflected in declining demand in for other activities, thus causing a general economic downturn. As described by (Myrdal, 1957), if the size of an economic downturn is so large that none of the sectors of the economy can absorb the unemployment caused by the closure of the an industry, unemployed workers have nothing else to do but emigrate.

\section{The Literature on Urban Concentration and Economic Growth}

Neoclassical theory emphasizes the fact that agglomeration and business concentration in a given area are is advantageous due to the spillover effect between firms, ease of communication and transportation, proximity to suppliers, a broad labor market, and availability of skilled workers (Marshall, 1890). Metropolitan areas generally perform better, because they are faster to restructure and catch up with economic change.; They are also they are preferred by foreign investors as a residential base because they are more connected and more integrated into the global economy (David, Peeters, Van Hamme, \& Vandermotten, 2013; see also Komlosi \& Balazs, 2016). The openness of metropolitan areas to internationalization and globalization attracts new businesses which, if operating in technologically advanced sectors, have a greater local multiplier in employment than traditional jobs in local non-tradable sector like restaurants, real estate, cleaning services, legal services (Moretti \& Thulin, 2013; see also Moretti, 2010). The peculiarity of modern technologies is that, due to their complexity, productivity increases exponentially because of the accumulation of experiences and that thus, an early lead adoption may corner the market of potential adopters (Arthur, 1989). The faster and stronger the economic change is, the deeper the deeper is the uneven territorial and economic development between metropolitan areas opened to globalization and rural peripheries or old industrial metropolitan regions becomes (Rumpel \& Slach, 2012). The inherent tendency toward sharpening of regional inequalities is more dominant in poor countries and it is characteristic of the laws of economics under laissez-faire (Myrdal, 1957).

\section{Reciprocal Relationships: Market Size and Economic Development}

According to Henry Lefebvre (2018), a city is not merely a physical space but also a social space, an urban system including economic, political, cultural relations. Lefebvre, according to a Marxist vision, describes this social space as a superstructure generated by the base structure- $-\mathrm{e}$ - the industrial production system - - but then the city develops autonomously, assumes a separate identity, influences, and ultimately changes the very structure that generated it, so the urban moment through the second circuit of capital, related to consumption and financial speculation - builds its own environment (Lefebvre, 2018).

Market size attracts firms that offer products and services, but and the also the firms themselves are consumers, and that causes the market widening to widen (Hirschman, 1958). This principle of interconnection and circular inter-dependence of among the quantities: demand, earning power, and income, investment, and production, determines a circular causation that involves the field of social relations and has an impact on the social substrate. (Arthur, 1989). A virtuous circuit is triggered between the dimensions of urban areas and work opportunities. City dimensions will increase to a certain point extent until that the advantages offered by job opportunities will outweigh the disadvantages associated with the cost of living in a big city.

This reciprocal relationship between market size and economic development has been called "circular causation" by (Myrdal, 1957) and "positive feedback” by (Hirschman, 1958). Thus, production tends to concentrate where there is a large market, but the market will be large where manufacturers' production is concentrated.

\section{Hypotheses}

Assumed that metropolitan areas are more attractive to new businesses due to concentration, openness to internationalization, and globalization, we expect that growing populations in certain areas is are correlated with better job opportunities:

H1: There is a significant relationship between the increase of the urban population and job opportunities.

H2: There is a significant relationship between the increase of in urban population and job opportunities in sectors different from the primary sector.

H3: The increase of in urban population is significantly correlated with the shifting of the labor force from the primary sector toward other sectors. 


\section{Synopsis of the Research Design}

The methodological approach selected for this study was the quantitative and one describing relationships between the urban population as the independent variable and the employment situation as a dependent variable. To test the above- mentioned hypotheses are we used the logit and multinomial logit model multinomial logit model.

Logistic and multinomial logistic regression, where a dichotomous/categorical dependent variable may be predicted by an explanatory variable, is often used in research papers that investigate the relationship between unemployment and other variables such as education, gender, training, healthcare, etc. According to Cattaneo (2008), the probability of being unemployed is computed as $\Phi$ - the Cumulative Density Function of a Standard Normal Distribution - a probit (logit) function of personal characteristics and district of residence dummy variables. In Oancea, Pospisil, \& Dragoescu (2016), several logit models were used to estimate the probability of being unemployed by the educational level, gender, marital status, and residence. Unemployment has been associated with poor self-assessed health including also other control variables such as business cycle fluctuations and individual variables such as age, gender, the level of education, etc. (Böckerman \& Ilmakunnas, 2007). Fabrizi \& Mussida (2009) used a multinomial logit model, upon with data from longitudinal studies, aimed to estimate transition probabilities between labor market states status (employed, - unemployed, - inactive) as averages of heterogeneous individual transition probabilities that are likely to depend on individual characteristics as well as on the general conditions of the labor market.

In this study, we used the logistic and multinomial logistic regression, and we supposed that the dependent variable- the employment status of the subject observed - - may be predicted by the density of the population resident in its territorial administrative unit. Albania is a small country, with a small population and, consequently, a substantially homogeneous distribution of characteristics. For this reason, we decided to rely solely on the density of the resident population as an explanatory variable of the employment situation of the observed subjects.

\section{Method and Source of Data}

Regarding For the first hypothesis, we used the logit model that is a nonlinear regression statistical model where the dependent variable may assume only two possible outcomes. The explanatory variable, on the other hand, while the explanatory variable is a continuous variable (Greene, 2011). It takes the form:

$\operatorname{Pr}\left(\mathrm{Y}_{\mathrm{it}}=1 \mid \mathrm{X}_{\mathrm{it}}\right)=\Phi\left(\mathrm{X}_{\mathrm{it}} \beta\right)$

where:

Pr represents the probability that $Y_{i t}=1$

$Y_{i t}$ is the status of a person on the job market, resident in the district $i$ at the time $t$ was observed during the LFS. In our panel of data, it assumes categorical values from $0=$ Unemployed/Inactive to $1=$ Employed. An individual is classified as employed if s/he has worked at least an hour in the reference week, which, in general, is the week preceding the survey. $\Phi$ represents the Cumulative Distribution Function of a standard normal random variable. $X_{i t}$ stands for the explanatory variable, the explanatory variable is the population resident in the urban area of the district $i$ at the time $t$ of the person subject of interview through the LFS. $i$ - the district of residence of the subject observed. In Albania, the district is a territorial administrative unit that includes a main municipality - - the main city which gives its name to the district - - and some secondary municipalities. Albanian territory is divided into 12 districts, the codification of which is as follows: (1="'Berat”, $2=$ “”Dibër”, 3=” “Durrës”, 4= “”Elbasan”, 5= “”Fier”, 6=” “ Gjirokastër”, 7=” “Korçë”, 8=“”Kukës”, 9=“"”Lezhë”, 10= “”Shkodër”, 11=” “Tiranë”, 12= “”Vlorë”. The abbreviation $t$ represents the year of observation; $t \in\{2007 ; 2013\}$ And $\beta$ stands for the parameter is estimated by the maximum likelihood of having observed this particular Y.

The marginal effect on the dichotomous dependent variable is estimated as an average of the marginal effect on the probabilities that $\operatorname{Pr}\left(Y_{i t}=1 \mid X_{i t}\right)$ because of marginal changes in the continuous explanatory variable $X_{i t}$. In this study, the data of the population resident in a district, is expressed in thousands, therefore, a marginal change of one unit of the dependent variable $X_{i t}$ corresponds to a change of 1.000 residents.

The validity of a model is measured by the percentage of the answers correctly predicted by the model. In a binary response, in which the possible values are only two, zero, and one, the casual probability of a correct answer is 50\%; therefore, the model is to be considered valid if the predicted probability is significantly higher than $50 \%$.

To test the second and the third hypothesis, we used the multinomial logit model that which is an extension of the binary logit model, but here, the outcome may assume more than two categories, $\mathrm{Y} \in(1,2,3,4 \ldots \ldots . \mathrm{n})$ or multiple categories. This test evaluates the probability, that, depending on the explanatory variable, the outcome may assume a different model from the most represented category named 
as the base outcome. Regarding the second hypothesis, in the multinomial logit model:

$Y_{i t}$ - the dependent variable is the category of the job of an employed person resident in the district $i$ at the time $t$. The ten major categories according to the International Standard Classification of Occupations (ISCO 2008) are: 1 = "Managers,", 2 = "Professionals,", 3 = "Technicians and associate professionals,", 4 = "Clerical support workers,", 5 = "Service and sales workers,", 6 = "Skilled agricultural, forestry, and fishery workers,", 7 = "Craft and related trades workers,", 8 = "Plant and machine operators, and assemblers,", 9 = "Elementary occupations.”. The category "Armed forces occupations" has been excluded from this analysis. ${ }^{1}$

$X_{i t}$ - the population resident in the urban area of the district $i$ at the time $t$.

Regarding For the third hypothesis, we assumed that the growth of the urban population positively affects job opportunities for better- educated workers. The outcome of interest is categorically distributed into four choices or / categories. In this model:

$Y_{i t}$ - the dependent variable is the education level of an employed person resident in the district $i$ at the time $t$. The categories are: 1 = "No School”, "2 = "Primary Education,", 3 = "Secondary Education”, 4 = "Tertiary Education”.

$X_{i t}$ - is the population resident in the urban area of the district $i$ at the time $t$.

Our source of data, i.e. the employment status of the persons interviewed, are is the Labor Force Surveys (LFS) in Albania $^{2}$ for the period 2007 - 2013; LFS includes information on districts of residence, age, gender, employment status, activity sector, education.
Demographic data, i.e. the population resident in the district $\mathrm{i}$ at the time t, were obtained from the Instat's population reports.

A major problem with the labour force surveys is that the employed or self-employed in the agriculture sector are reported qualitatively the same as the employed in industry or tertiary sector, even though they might have been working only for one day during the last week before the survey was carried out. Therefore, we decided to exclude them in the tests for the second hypothesis we have decided to exclude them.

The data has been pre-processed (inspected, cleaned, and transformed) for analysis purposes without compromising the integrity of the original data. Statistical analyses were performed using the Stata software package.

\section{Limitations}

A One major limitation of this research is that the period of analysis was e limited period of only seven years from 2007 to 2013.

Another limitation, in our opinion, is related to the definition of a person as "employed" as "a person who during the last week before the survey has worked at least one hour, even on a farm owned or rented by him or a member of his household (even unpaid).”. Given that a very large share - 49\% — of the labour force in Albania works $49 \%$ - work in the agriculture sector., in our opinion this may distort the real numbers of the unemployed because many of those see employed in agriculture may prefer a regular paid job but are forced to work on their small farms due to a lack of opportunities.

Table 1. Urban Population and Districts

\begin{tabular}{lccccc} 
Variable & Obs & Mean & Std. Dev. & Min & Max \\
\hline UrbanPopul_k & 67693 & 189.1708 & 168.9427 & 28.3765 & 552.9084 \\
\hline District & 67693 & 6.467966 & 3.728625 & 1 & 12 \\
\hline
\end{tabular}

\footnotetext{
${ }^{1}$ Classification of the categories of jobs follows the International Labour Organization (ILO) classification according to the International Standard Classification of Occupations (ISCO 2008).

${ }^{2}$ Institute of Statistics Albania (http://www.instat.gov.al/en/).
} 


\section{Findings and Results}

H1: There is a significant relationship between the increase of the urban population and job opportunities.

The first set of analysis analyses tested the hypothesis that an increase in the urban population is correlated with an increase of in the employed. As summarized in Table 2. Logistic model H.1, an increase in the population resident in urban areas (UrbanPopul_k) does not increase the likelihood that the dependent variable - the status of the subject observed (WSTATOR) - is "Employed", $Y=1$. The $\beta$ coefficient is negative (-.0005462), meaning that an increase of the urban population resident in a district makes the outcome $\mathrm{Y}=1$ (employed) in that district less likely.

The accuracy of fit measures of the model, measured by the percentage of correctly predicted values, is $51 \%$, basically the same probability, $50 \%$, of a correct choice from a random selection between 0 and 1 (Table 3. Logistic model estimation H.1). Therefore, we may conclude that a pattern does not emerge from this test and the model has no prediction validity.

H2: There is a significant relationship between the increase of urban population and job opportunities in sectors different from the primary sector.

If we exclude the employees in the agriculture sector from our analysis, the logit test on 52281 observations indicates that at the 0.01 significance level, the sign of $\beta$ coefficient is positive (.0008135) Table 4. Logistic model H.2. Therefore, we cannot exclude the hypothesis that an increase in the population resident in urban areas does not increase the likelihood that the subject observed is "Employed", $\mathrm{Y}=1$.

The average marginal effect of urban population growth of 1000 units on the probability that $Y=1$ ("Employed") in a sector different from agriculture in that district is $+0.02 \%$ (Table 5.Average marginal effects H.2). The consequences on large numbers mean that the probability of a person resident in the district of Tirana (552.000 inhabitants in 2013) to be employed is $10 \%$ higher than that of a person resident in the district of Kukes (28.000 inhab. 2013).

The percent of correctly predicted values is $67 \%$, significantly higher than the probability from a random selection between 0 and 1 that is $50 \%$, and therefore we may conclude that the model has significant prediction validity ( $\mathrm{Ta}$ ble 6. Logistic model estimation H.2).

H3: The increase of the urban population is significantly correlated with the shifting of the labor force from the primary sector toward other sectors.
Regarding the third hypothesis, the multinomial logit test on 32540 observations, with a confidence of 99\%, cannot exclude the positive correlation between urban population growth and the shift of the employees from "Agriculture, Forestry and Fishing” jobs towards other sectors (Table 7.Multinomial logistic regression H.3.)

The average marginal effect of population growth is higher for three activities or /occupations in particular: $\mathrm{Y}=5$ “Service Worker,", $\mathrm{Y}=2$ "Professionals and Sales," and $\mathrm{Y}$ = 7 "Craft and Related Trades Workers" (Table 8. Average marginal effects H.3). The greatest marginal effect occurs in the agriculture, forestry, and fishing sector, $-0.1 \%$. The probability that an employee, residing in the largest city or / district of Tirana, is employed in the agricultural sector is $50 \%$ lower than an employee residing in less populated cities, such as Kukes.

\section{Discussion}

In this paper, we did not find a correlation between urban population increase and job opportunities in general. But if we exclude the employed in the agriculture sector, then the chances for employment will increase with the increase of the urban population; the most affected job categories are “qualified professionals” and "service activities workers.”. In fact, the reliability of official data on unemployment is a common problem in underdeveloped countries, as they are often affected by distortions such as a work force employed in agriculture which ere this sector can represent almost half of the employed work force, whereas, in the developed countries it barely is higher than 2-3\%. Consequently, our main interests have been the employed in activities different from agriculture and our research found interesting dynamics between an increasing population in urban areas and job opportunities.

The overall pattern was that the growth of the population in urban areas carries the necessity for qualified professionals. First, a large urban area means a larger market that favors the division of labor. Second, metropolitan areas being more open and sensitive to internationalization, are more oriented towards an exchange, which also favors specialization. It follows that the probabilities of finding a skilled job increase with the population of cities.

These results are consistent with those observed in earlier studies of (Moretti, 2010)Moretti (2010): an increase in high-qualification employment activities has a spillover effect across the labor market, as any new qualified job leads to a progressive increase in the other service sector jobs. Regarding the circular causation between the extent of the market and the skills of workers, it that is a discussion topic that may need further research. 


\section{Conclusions}

The results of this study in-Albania between 2007-2013 indicated that there has been ae existence of a correlation between the dimensions of the urban population and job opportunities different from those in the agriculture.

Even though the Albanian economy has shown a satisfactory average economic growth in the last 20 years of, $4 \%,{ }^{3}$, the structure of the economy is distorted if we analyzed it from the perspective of the distribution of the workforce across economic sectors. Almost half of the workforce is employed in the agricultural sector while this sector contributes only $18.5 \%{ }^{4}$ into the GDP. for only $18.5 \%$.

Two conclusions can be drawn. First, basically employment in agriculture is rather more a mandatory choice, than a true job alternative. Second, the future of employment lies on economic sectors other than agriculture, such as in services, specialized professionals, and crafts, which proved to be the more active and dynamic in our study result to be more active and dynamic.

The implications for public policy recommendations are a consequence of the consideration, that the high number of employees in agriculture, which is indicative of is an indicator of technological backwardness in this sector where in which work is still labour intensive and mostly manual work. Hence, it can be concluded that a greater commitment to the technological modernization of this sector is needed. Another recommendation relates to the fact that efforts and investments are needed to improve the quality of human capital. to be addressed in terms of an increase in the quality of human capital. The process of urbanization and the concentration of the population in urban areas is inevitable; however, it is the responsibility of a policy to facilitate and make less traumatic the shift of the workforce from the backward sectors of agriculture towards more dynamic and productive activities.

\section{References}

Arthur, W. B. (1989). Competing Technologies, Increasing Returns, and Lock-in by Historical Events. The Economic Journal, 99(394), 116-131. https://doi.org/10.2307/2234208

Böckerman, P., \& Ilmakunnas, P. (2007). Unemployment and Self-assessed health: Evidence from panel data. HECER - Helsinki Center of Economic Research, Discussion Paper No. 148 ISSN 1795-0562 https://doi.org/10.2139/ssrn.962834

Bukowski, M., \& Lewandowski, P. (2005). Transitions from Unemployment in Poland: A Multinomial Logit Analysis. Labor and Demography 0511008, University of Munich, Germany.

Cattaneo, C. (2008). The Determinants of Actual Migration and the Role of Wages and Unemployment in Albania: An Empirical Analysis. The European Journal of Comparative Economics, 5(1), 3-32.

Chapman, S., \& Meliciani, V. (2018). Explaining Regional Disparities in Central and Eastern Europe: The role of geography and of structural change. The Economics of Transition, 469-494.

David, Q., Peeters, D., Van Hamme, G., \& Vandermotten, C. (2013). Is bigger better? Economic Performances of European Cities, 1960-2009. Cities, 35, 237-254. https://doi.org/10.1016/j.cities.2013.07.011

Fabrizi, E. (2009). The Determinants of Labour Market Transitions. Giornale degli Economisti, 233-265.

Greene, W. (2011). Econometric Analysis. New Jersey: Prentice -Hall.

Haase, A., Grossmann, K., \& Rink, D. (2016). Shrinking cities in postsocialist Europe - what can we learn from their analysis for urban theory-making? Geografiska Annaler: Series B, 305-319.

Headey, D., \& Hodge, A. (2009). The Effect of Population Growth on Economic Growth: A Meta-Regression Analysis of the Macroeconomic Literature. Population and Development Review, 221-248 . https://doi.org/10.1111/j.1728-4457.2009.00274.x

Hirschman, A. (1958). The Strategy of Economic Development. New Haven: Yale University Press Pp. xiii, 217

Instat. (2014). Migracioni ne Shqiperi. Tirana: Instituti i Statistikave Shqiperi. URL: http://www.instat.gov.al/media/3078/migracioni_ne_shqiperi.pdf

Instat. (2018). Diaspora e Shqiperise ne Shifra. Tirana: Instituti i Statistikave Shqiperi. URL: http://www.instat.gov.al/al/publikime/ librat/2018/diaspora-e shqip\%C3\%ABris\%C3\%AB-n\%C3\%AB-shifra-2018/

\footnotetext{
${ }^{3}$ World Bank Open Data. - https://data.worldbank.org/indicator/NY.GDP.MKTP.KD.ZG?locations=AL

${ }^{4}$ Instat. http://www.instat.gov.al/al/statistikat-në-shkolla/prodhimi-i-brendshëm-bruto/

${ }^{5}$ Instat - http://www.instat.gov.al/al/statistikat-në-shkolla/prodhimi-i-brendshëm-bruto/
} 
Komlosi, E., \& Balazs, P. (2016). The Impact of Urban Concentration on Countries' Competitiveness and Entrepreneurial Performance. Regional Statistics, 97-120. https://doi.org/10.15196/RS05106

Kopliku, B. (2016). Migrimi i Brendshem ne Rajonin e Shkodres gjate viteve 1945 - 1990. Buletini Shkencor Universiteti i Shkodres, Seria Shkencat Shoqerore.

Maestas, N., Mullen, K., \& Powell, D. (2016). The Effect of Population Aging on Economic Growth, the Labor Force and Productivity. NBER Working Paper No. 22452. https://doi.org/10.3386/w22452

Marshall, A. (1890). Principles of Economics. London: Macmillan and Co. London and New York, Vol. I, pp. xxviii, 754

Moretti, E. (2010).Local Multipliers. American Economic Review: Papers \& Proceedings 100,1 - 7.https://doi.org/10.1257/aer.100.2.373

Moretti, E., \& Thulin, P. (2013). Local multipliers and human capital in the United States and Sweden. Industrial and Corporate Change, 339-362. https://doi.org/10.1093/icc/dts051

Myrdal, G. (1957). Economic theory and under-developed regions. Gerald London: Duckworth.

Oancea, B., Pospisil, R., \& Dragoescu, R. (2016). A logit model for the estimation of the educational level influence on unemployment in Romania. Knowledge for Market Use - Our Interconnected and Divided World. Olomouc, Czech Republic.

Petrakos, G. (2001). Patterns of Regional Inequality in Transition Economies. European Planning Studies, 9, $359-383$.

Pociūtè-Sereikienè, G. (2019). Peripheral Rgions in Lithuania: The Results of Uneven Development. Regional Studies, Regional Science, 70-77. https://doi.org/10.1080/21681376.2019.1571437

Romanova, E., Vinogradova , O., \& Frizina , I. (2015). Social and Economic Space Compression in Border Areas: The cCase of the Northwestern Federal District. Baltijskij Region, 38-61. https://doi.org/10.5922/2074-9848-2015-3-3

Rumpel, P., \& Slach, O. (2012). Shrinking Cities in Central Europe. Czech Sociological Review , 859-878.

Šerý, O., Svobodová, H., Šilhan, Z., \& Szczyrba, Z. (2017). Shrinking of Citcities in the Czech Republic and its rReflection on sSociety: Case sStudy of Karviná City. Geographica Pannonica 22. https://doi.org/10.5937/22-16622

Smetkowski, M. (2013). Regional dDisparities in Central and Eastern European Countries: Trends, dDrivers, and pProspects. Europe-Asia Studies, 1529-1554. https://doi.org/10.1080/09668136.2013.833038

Turok, I., \& Mykhnenko, V. (2007). The Trajectories of European Cities, 1960-2005. Cities, 24(3), 165-182. https://doi.org/10.1016/j. cities.2007.01.007 


\section{Appendix}

Table 2. Logistic model H.1

\begin{tabular}{lcccccc} 
WSTATOR & Coef. & Std. Err. & $\mathbf{z}$ & P>z & [95\%Conf. & Interval] \\
\hline UrbanPopul_k & -0.00055 & 0.0000458 & -11.93 & 0 & -0.00064 & -0.00046 \\
\hline _cons & 0.02217 & 0.011552 & 1.92 & 0.055 & -0.00047 & 0.044811 \\
\hline
\end{tabular}

Logistic regression

Number of obs $=67693$

LR chi2(1) $=143.04$

Prob $>$ chi2 $=0.0000$

Log likelihood $=-46794.345 \quad$ Pseudo R2 $=0.0015$

Table 3. Logistic model estimation H.1

\begin{tabular}{l|cc|c} 
& \multicolumn{1}{|c|}{ True } & \\
\hline Classified & D & $\sim D$ & Total \\
\hline+ & 2879 & 3382 & 6261 \\
\hline- & 29599 & 31833 & 61432 \\
\hline Total & 32478 & 35215 & 67693 \\
\hline
\end{tabular}

Classified + if predicted $\operatorname{Pr}(D)>=0.5$

True $D$ defined as WSTATOR $!=0$

\begin{tabular}{|c|c|c|c|c|}
\hline Sensitivity & & $\operatorname{Pr}(+D)$ & $8.86 \%$ & \\
\hline Specificity & & $\operatorname{Pr}(-\sim D)$ & $90.40 \%$ & \\
\hline Positive predictive value & & $\operatorname{Pr}(D+)$ & $45.98 \%$ & \\
\hline Negative predictive value & & $\operatorname{Pr}(\sim \mathrm{D}-)$ & $51.82 \%$ & \\
\hline False + rate for true $\sim D$ & & $\operatorname{Pr}(+\sim D)$ & $9.60 \%$ & \\
\hline False - rate for true D & & $\operatorname{Pr}(-D)$ & $91.14 \%$ & \\
\hline False + rate for classified & + & $\operatorname{Pr}(\sim D+)$ & $54.02 \%$ & \\
\hline False - rate for classified & - & $\operatorname{Pr}(\mathrm{D}-)$ & $48.18 \%$ & \\
\hline Correctly classified & & & & $51.28 \%$ \\
\hline
\end{tabular}


Table 4. Logistic model H.2

\begin{tabular}{lcccccc} 
WSTATOR & Coef. & Std. Err. & $\mathrm{z}$ & $\mathrm{P}>\mathrm{z}$ & {$[95 \%$ Conf. } & Interval] \\
\hline UrbanPopul_k & 0.0008 & $5.16 \mathrm{E}-05$ & 15.77 & 0 & 0.000712 & 0.000915 \\
\hline cons & -0.893 & 0.014444 & -61.84 & 0 & -0.92152 & -0.8649 \\
\hline
\end{tabular}

Logistic regression

Number of obs $=52281$

LR chi2(1) $=246.19$

Prob $>$ chi2 $=0.0000$

Log likelihood $=-32911.671 \quad$ Pseudo R2 $=0.0037$

Table 5. Average marginal effects H.2

\begin{tabular}{lcccccc} 
Std. Err. & $\mathrm{dy} / \mathrm{dx}$ & Std. Err. & $\mathrm{z}$ & $\mathrm{P}>\mathrm{z}$ & [95\% Conf. & Interval] \\
\hline UrbanPopul_k & 0.0002 & $1.12 \mathrm{E}-05$ & 15.91 & 0 & 0.000156 & 0.0002 \\
\hline
\end{tabular}

Average marginal effects

Number of obs $=52281$

Model VCE : OIM

Table 6. Logistic model estimation H.2

\begin{tabular}{l|cc|c} 
& \multicolumn{2}{|c|}{ True } & \\
\hline Classified & $\mathrm{D}$ & $\sim \mathrm{D}$ & Total \\
\hline+ & 0 & 0 & 0 \\
\hline- & 17084 & 35197 & 52281 \\
\hline Total & 17084 & 35197 & 52281 \\
\hline
\end{tabular}

Classified + if predicted $\operatorname{Pr}(\mathrm{D})>=0.5$

Classified + if predicted $\operatorname{Pr}(\mathrm{D})>=0.5$

\begin{tabular}{|c|c|c|c|}
\hline Sensitivity & & $\operatorname{Pr}(+D)$ & $0.00 \%$ \\
\hline Specificity & & $\operatorname{Pr}(-\sim D)$ & $100.00 \%$ \\
\hline Positive predictive value & & $\operatorname{Pr}(D+)$ &.$\%$ \\
\hline Negative predictive value & & $\operatorname{Pr}(\sim \mathrm{D}-)$ & $67.32 \%$ \\
\hline False + rate for true $\sim D$ & & $\operatorname{Pr}(+\sim D)$ & $0.00 \%$ \\
\hline False - rate for true D & & $\operatorname{Pr}(-D)$ & $100.00 \%$ \\
\hline False + rate for classified & + & $\operatorname{Pr}(\sim D+)$ & $\%$ \\
\hline False - rate for classified & - & $\operatorname{Pr}(\mathrm{D}-)$ & $32.68 \%$ \\
\hline Correctly classified & & & $67.32 \%$ \\
\hline
\end{tabular}


Table 7. Multinomial logistic regression H.3

\begin{tabular}{|c|c|c|c|c|c|c|c|}
\hline & ISCO_1_DIGIT & Coef. & Std. Err. & z & $P>z$ & [95\% Conf. & Interval] \\
\hline \multirow[t]{2}{*}{ 1- Managers } & UrbanPopul_k & 0.0043531 & 0.0001872 & 23.25 & 0 & 0.003986 & 0.00472 \\
\hline & _cons & -3.61406 & 0.0552842 & -65.37 & 0 & -3.72242 & -3.50571 \\
\hline \multirow[t]{2}{*}{2 - Professionals } & UrbanPopul_k & 0.0040275 & 0.0001223 & 32.92 & 0 & 0.003788 & 0.004267 \\
\hline & _cons & -2.414009 & 0.0326103 & -74.03 & 0 & -2.47792 & -2.35009 \\
\hline \multirow[t]{2}{*}{$\begin{array}{l}3 \text { - Technicians and } \\
\text { associate professionals }\end{array}$} & UrbanPopul_k & 0.0038061 & 0.0001762 & 21.6 & 0 & 0.003461 & 0.004152 \\
\hline & _cons & -3.279774 & 0.0487651 & -67.26 & 0 & -3.37535 & -3.1842 \\
\hline \multirow[t]{2}{*}{$\begin{array}{l}4 \text { - Clerical } \\
\text { support workers }\end{array}$} & UrbanPopul_k & 0.0045207 & 0.0002356 & 19.19 & 0 & 0.004059 & 0.004982 \\
\hline & _cons & -4.187344 & 0.0720991 & -58.08 & 0 & -4.32866 & -4.04603 \\
\hline \multirow[t]{2}{*}{$\begin{array}{l}5 \text { - Service and sales } \\
\text { workers }\end{array}$} & UrbanPopul_k & 0.0036803 & 0.0001131 & 32.54 & 0 & 0.003459 & 0.003902 \\
\hline & _cons & -2.051576 & 0.0285384 & -71.89 & 0 & -2.10751 & -1.99564 \\
\hline $\begin{array}{l}6 \text { - agricultural, forestry, } \\
\text { and fishery workers }\end{array}$ & \multicolumn{7}{|c|}{ (base outcome) } \\
\hline \multirow[t]{2}{*}{$\begin{array}{l}7 \text { - Craft and related } \\
\text { trades workers }\end{array}$} & UrbanPopul_k & 0.0033815 & 0.0001144 & 29.57 & 0 & 0.003157 & 0.003606 \\
\hline & _cons & -1.978198 & 0.028129 & -70.33 & 0 & -2.03333 & -1.92307 \\
\hline \multirow[t]{2}{*}{$\begin{array}{l}8 \text { - Plant and machine } \\
\text { operators, assemblers }\end{array}$} & UrbanPopul_k & 0.0034789 & 0.0001483 & 23.45 & 0 & 0.003188 & 0.00377 \\
\hline & _cons & -2.739443 & 0.0387819 & -70.64 & 0 & -2.81545 & -2.66343 \\
\hline \multirow[t]{2}{*}{$\begin{array}{l}9 \text { - Elementary } \\
\text { occupations }\end{array}$} & UrbanPopul_k & 0.0036654 & 0.0001318 & 27.8 & 0 & 0.003407 & 0.003924 \\
\hline & _cons & -2.49648 & 0.03446 & -72.45 & 0 & -2.56402 & -2.42894 \\
\hline
\end{tabular}

Table 8. Average marginal effects H.3

\begin{tabular}{|c|c|c|c|c|c|c|c|c|}
\hline & variable & $d y / d x$ & Std. Err. & $\mathrm{z}$ & $\mathrm{P}>\mathrm{Z}$ & [ 95\% & C.I. ] & $x$ \\
\hline 1-Managers & Urban _k & 0.0000653 & 0 & 14.13 & 0 & 0.000056 & 0.000074 & 181.043 \\
\hline 2 - Professionals & Urban _k & 0.000176 & 0.00001 & 20.89 & 0 & 0.00016 & 0.000193 & 181.043 \\
\hline $\begin{array}{l}3 \text { - Technicians and } \\
\text { associate professionals }\end{array}$ & Urban _k & 0.0000636 & 0.00001 & 11.51 & 0 & 0.000053 & 0.000074 & 181.043 \\
\hline $\begin{array}{l}4 \text { - Clerical support } \\
\text { workers }\end{array}$ & Urban _k & 0.0000407 & 0 & 11.75 & 0 & 0.000034 & 0.000047 & 181.043 \\
\hline $\begin{array}{l}5 \text { - Service and sales } \\
\text { workers }\end{array}$ & Urban _k & 0.000198 & 0.00001 & 19.59 & 0 & 0.000178 & 0.000217 & 181.043 \\
\hline $\begin{array}{l}6 \text { - agricultural, forestry, } \\
\text { and fishery workers }\end{array}$ & Urban _k & -0.00093 & 0.00002 & -46.49 & 0 & -0.00097 & -0.00089 & 181.043 \\
\hline $\begin{array}{l}7 \text { - Craft and related } \\
\text { trades workers }\end{array}$ & Urban _k & 0.000166 & 0.00001 & 15.87 & 0 & 0.000145 & 0.000186 & 181.043 \\
\hline $\begin{array}{l}8 \text { - Plant and machine } \\
\text { operators, assemblers }\end{array}$ & Urban__k & 0.0000843 & 0.00001 & 11.64 & 0 & 0.00007 & 0.000099 & 181.043 \\
\hline $\begin{array}{l}9 \text { - Elementary } \\
\text { occupations }\end{array}$ & Urban _k & 0.000125 & 0.00001 & 15.38 & 0 & 0.000109 & 0.000141 & 181.043 \\
\hline
\end{tabular}




\section{Rast mestnega prebivalstva in zaposlitvene možnosti: primer Albanije}

\section{Izvleček}

Demografske spremembe so večplasten pojav, toda na splošno je sprejeto, da med pomembnejše dejavnike, ki določajo mobilnost ljudi, spadajo boljše zaposlitvene možnosti in kakovost delovnih mest. Namen tega prispevka je preizkusiti razmerje med povečanjem števila ljudi, ki živijo v mestnih območjih, in možnostmi zaposlitve na teh območjih v Albaniji; $v$ ta namen smo izvedli statistično analizo zbirke podatkov iz anket o delovni sili za časovno obdobje 2007-2013. Naše ugotovitve potrjujejo pozitivno povezavo med povečanjem števila posameznikov, ki živijo na določenem območju, in možnostmi zaposlitve za specializirane poklice na tem območju; vendar pa ob upoštevanju splošne možnosti zaposlitve pomembne povezave ni bilo mogoče najti.

Ključne besede: rast mestnega prebivalstva, možnosti zaposlitve, Albanija, gospodarstva v tranziciji, demografske spremembe, notranja migracija 